\title{
Fusobacterium perfoetens (Tissier) Moore and Holdeman 1973: Description and Proposed Neotype Strain
}

\author{
PAUL F. VAN ASSCHE AND ALBERT T. WILSSENS \\ Laboratory of Industrial Fermentation, Faculty of Agricultural Sciences, University of Gent, \\ 9000 Gent, Belgium
}

In 1900, Tissier described a new bacterium, Coccobacillus anaerobius perfoetens, that he isolated from an infant with diarrhea and, in 1905, from nursing infants. This organism was placed by Hauduroy et al. (1937) in the genus Bacteroides, by Sebald (1962) in Sphaerophorus, and then by Moore and Holdeman (1973) in the genus Fusobacterium. Sphaerophorus perfoetens CC1, isolated in 1947 by Prévot from the cecum of a horse and studied by Sébald in 1962, has been lost. Since then, no strains conforming to the description of Tissier's organism have been known to be extant. However, recently we obtained from a normal piglet six isolates that conform to the original and subsequent descriptions of this organism. One of these isolates, PVA $\mathrm{B}_{3} / 63$, is designated as the neotype strain of Fusobacterium perfoetens and is available from the American Type Culture Collection as ATCC 29250.

In 1900, Tissier (11) isolated a gram-negative, anaerobic, nonsporeforming organism from an infant with diarrhea and named the organism Coccobacillus anaerobius perfoetens. In 1905, he isolated the same organism from nursing infants.

In 1947, Prévot isolated an identical strain from the cecum of a horse. This strain, CC1, was studied by Sébald in 1962 (10) and was transferred by her to the genus Sphaerophorus as $\boldsymbol{S}$. perfoetens. Subsequently, the cultures of this strain were lost.

On the basis of the published descriptions of this organism, Moore and Holdeman (7) transferred the organism to the genus Fusobacterium as $F$. perfoetens.

Recently, we isolated from the feces of a piglet a strain whose characters agree not only with those in the original description of this organism by Tissier but also with those in subsequent descriptions $(5,8,11)$.

The purpose of this paper is to update the description of Fusobacterium perfoetens (Tissier) Moore and Holdeman and to designate the neotype strain for it.

\section{MATERIALS AND METHODS}

Bacterial strains. We recently obtained six isolates from the feces of a 2-week-old normal piglet. The isolates were designated PVA $\mathrm{B}_{3} / 5$, PVA $\mathrm{B}_{3} / 6$, PVA $_{3} / 31$, PVA $B_{3} / 31 b$, PVA $B_{3} / 34$, and PVA $B_{3} / 63$. One of the isolates, PVA $\mathrm{B}_{3} / 63$, was deposited in the American Type Culture Collection (ATCC), Rockville, Md., under the number 29250.

Media. Initial isolation of organisms from fecal material was made by enrichment in regenerated modified Rosenow medium (1). Colonies were picked from solid VL blood medium without selection and were incubated at $37^{\circ} \mathrm{C}$ in GasPak (BBL) jars using a GasPak $\mathrm{H}_{2}-\mathrm{CO}_{2}$ generator for the gaseous phase.

Cultures of the isolates were maintained in modified Rosenow medium (1), covered with paraffin, and stored deep-frozen at $-20^{\circ} \mathrm{C}$. The composition of the medium is as follows: proteose peptone no. 3 (Difco), $10 \mathrm{~g}$; beef extract (Difco), $3 \mathrm{~g}$; NaCl, $5 \mathrm{~g}$; glucose, $2 \mathrm{~g}$; cysteine hydrochloride, $0.3 \mathrm{~g}$; Andrade solution (5\% fuchsin), $10 \mathrm{ml}$; and distilled water, $1,000 \mathrm{ml}$; the $\mathrm{pH}$ was adjusted to 7.2 . The medium was distributed in tubes, each containing $0.5 \mathrm{~g}$ of frozen beef brain and a piece of marble, and was sterilized at $120^{\circ} \mathrm{C}$ for $20 \mathrm{~min}$.

Most of the biochemical tests were performed in VL base medium (1) to which supplements were added. The medium contained: tryptone (Oxoid), 10 $\mathrm{g} ; \mathrm{NaCl}, 5 \mathrm{~g}$; beef extract (Difco), $2 \mathrm{~g}$; yeast extract (Difco), $5 \mathrm{~g}$; cysteine hydrochloride, $0.3 \mathrm{~g}$; agar, 0.5 g; and distilled water, 1,000 ml. For the solid VL blood medium, $0.2 \%$ glucose, $2 \%$ agar, and $10 \%$ defibrinated horse blood were added to the VL base medium.

Methods. Cellular morphology was determined by examination of Gram-stained smears (Kopeloff modification) as described by Holdeman and Moore (4). The purity of each culture was checked by aerobic and anaerobic subculture on VL blood agar. Catalase production was determined by adding 1 drop of a $3 \% \mathrm{H}_{2} \mathrm{O}_{2}$ solution to a colony on VL agar without blood, since false-positive results may occur due to the catalase in blood. These tests were performed both immediately after removing cultures from an anaerobic environment (anaerobic jar) and after at least a 1-h exposure to the air. The fermentation reactions were studied in VL base supplemented with a $1 \%$ carbon source. All carbohydrates and polyalcohols were membrane-filter sterilized as $10 \%$ ( $w t / v o l)$ solutions and added to the basal medium to give a final concentration of $1 \%$. The results were 
recorded after 7 days. Nitrate reduction and $\mathrm{H}_{2} \mathrm{~S}$ production tests were performed in VL base supplemented with $5 \mathrm{~g}$ of $\mathrm{NaNO}_{3}$ per liter and $2 \mathrm{~g}$ of glucose per liter, respectively, and with $0.2 \mathrm{~g}$ of $\mathrm{FeSO}_{4}$ per liter and $0.3 \mathrm{~g}$ of $\mathrm{Na}_{2} \mathrm{~S}_{2} \mathrm{O}_{3}$ per liter. The presence of nitrite was detected by adding 5 drops of $0.8 \%$ sulfanilic acid in $5 \mathrm{~N}$ acetic acid and 5 drops of $0.6 \% \alpha$ naphthylamine in $5 \mathrm{~N}$ acetic acid to cultures grown in the above-mentioned medium. A red color indicated the presence of nitrite. $\mathrm{H}_{2} \mathrm{~S}$ production was demonstrated by the blackening of the medium. Indole and $\mathrm{NH}_{3}$ production was determined on VL base by adding Kovac reagent or Nessler solution. Threonine deamination was determined by the method described by Buttiaux et al. (1).

The metabolic end products from peptone-yeast extract-glucose (PYG) medium and the production of propionic acid from threonine were detected by gas-liquid chromatography by the methods of Holdeman and Moore (4). Chromatography was performed on a Hewlett Packard 5700 A gas chromatograph with hydrogen flame detector and with helium as the carrier gas.

Peak areas were recorded with a digital integrator (model $3370 \mathrm{~A}$ ). Stainless-steel columns (length, $1.8 \mathrm{~m}$ [ 6 feet]; outer diameter, ca. $0.3 \mathrm{~cm}$ [ $1 / 8$ inch]) containing $10 \%$ Carbowax on Diatoport W were used.

Other operating conditions were: sample size, 3 $\mu \mathrm{l}$; carrier make-up flow, $60 \mathrm{ml} / \mathrm{min}$; inlet and detector temperature, $250^{\circ} \mathrm{C}$; and column temperature isothermal, $120^{\circ} \mathrm{C}$. Sample components were tentatively identified by comparison with standard volatile fatty acids and fatty acid methyl esters. For determination of deoxyribonucleic acid (DNA) base composition, DNA was isolated from strain PVA $B_{3}$ / 63 by the method of Marmur (6). The percentages of guanine plus cytosine $(\mathrm{G}+\mathrm{C})$ in the DNA samples were determined from absorbancy ratios of the DNAs by using a quick method described by De Ley (2).

To demonstrate the antibiotic susceptibility of the strains, 6-mm paper disks containing the indicated amounts of antibiotic (susceptibility disks for antibiotics, BBL) were placed on VL blood agar plates streaked with the indicated organism, and these were incubated for 2 days in a GasPak anaerobic jar (BBL).

\section{RESULTS AND DISCUSSION}

Cellular morphology. The morphology of the six isolates was found to be exactly the same as that of the strains described by Weinberg et al. (12) and Prévot (8). The isolates were nonsporeforming, gram-negative, nonmotile, short, ovoid rods. The cells measured 0.6 to 0.8 by 0.8 to $1.0 \mu \mathrm{m}$; they were oval, never elongated, and occurred singly, in pairs, in chains of no more than three cells, or in irregular masses (Fig. 1) where each cell maintained its own shape. They did not elongate in old cultures but remained oval. The cell measurements were always greater in PYG than in Rosenow broth cultures (Fig. 2). No flagella or capsules were present.

Colonial morphology. Tissier (11) described 48-h-old deep-agar colonies as lenticular and 1 $\mathrm{mm}$ in diameter. We also found lenticular colonies which enlarged markedly on continued incubation in VL deep agar (6 $\mathrm{g}$ of agar per liter). Surface colonies of isolate PVA $B_{3} / 63$ on horse blood agar were 1 to $2 \mathrm{~mm}$ in diameter, circular with an entire edge, raised, and grayish-white to gray. Surface colonies of the other isolates were similar to those of PVA $B_{3} / 63$. However, colonies of some of the isolates were slightly umbonate and had diffuse edges and a slightly mottled or finely granular appearance.

Biochemical characteristics originally and subsequently described. As described by Weinberg et al. (12), the earlier isolated strains were obligately anaerobic, did not survive $60^{\circ} \mathrm{C}$ for 15 min, and lived for at least 1 month at room temperature in different media. Growth in glucose broth cultures was rapid, and a fine sediment, gas, and a fetid odor were produced. Glucose and sucrose were the only carbohydrates fermented; lactose was not fermented. Milk was not coagulated, and indole was not produced. $\mathrm{H}_{2} \mathrm{~S}, \mathrm{NH}_{3}$, and $\mathrm{CO}_{2}$ were produced. Lactic acid and only small amounts of butyric and valeric acids were produced from glucose.

Some additional biochemical information was provided in the classification manuals of anaerobic bacteria by Prévot (8) and Prévot et al. (9). These characteristics are included in Table 1, in which also are listed the characteristics of the six isolates.

Prévot (8) reported the production of acetic, butyric, valeric, and lactic acids from glucose. However, the metabolic products from glucose as summarized by Moore and Holdeman (5), and based upon literature descriptions by Weinberg et al. (12) and by Prévot et al. (9), are acetic, butyric, and lactic acids. In our laboratory, gas chromatographic analyses revealed, as major products, butyric acid ( 1 to 2 meq/100 $\mathrm{ml})$, lactic acid $(0.6$ to $1.3 \mathrm{meq} / 100 \mathrm{ml})$, acetic acid $(0.1$ to $0.6 \mathrm{meq} / 100 \mathrm{ml})$, and traces of propionic acid $(0.0$ to $0.1 \mathrm{meq} / 100 \mathrm{ml})$. The amount of acetic acid always was greater in PY $(0.5$ to $1.5 \mathrm{meq} / 100 \mathrm{ml}$ ) than in PY glucose. We believe that the chromatographic procedures available to us are more reliable than were the earlier distillation procedures used by Tissier and Prévot for the identification of the products.

The temperature for optimum growth is about $37^{\circ} \mathrm{C}$; strain PVA $\mathrm{B}_{3} / 63$ grows well in Rosenow medium at $45^{\circ} \mathrm{C}$, but it does not grow at $50^{\circ} \mathrm{C}$ and grows only sparsely at 25 to $30^{\circ} \mathrm{C}$. No growth was observed after aerobic incuba- 


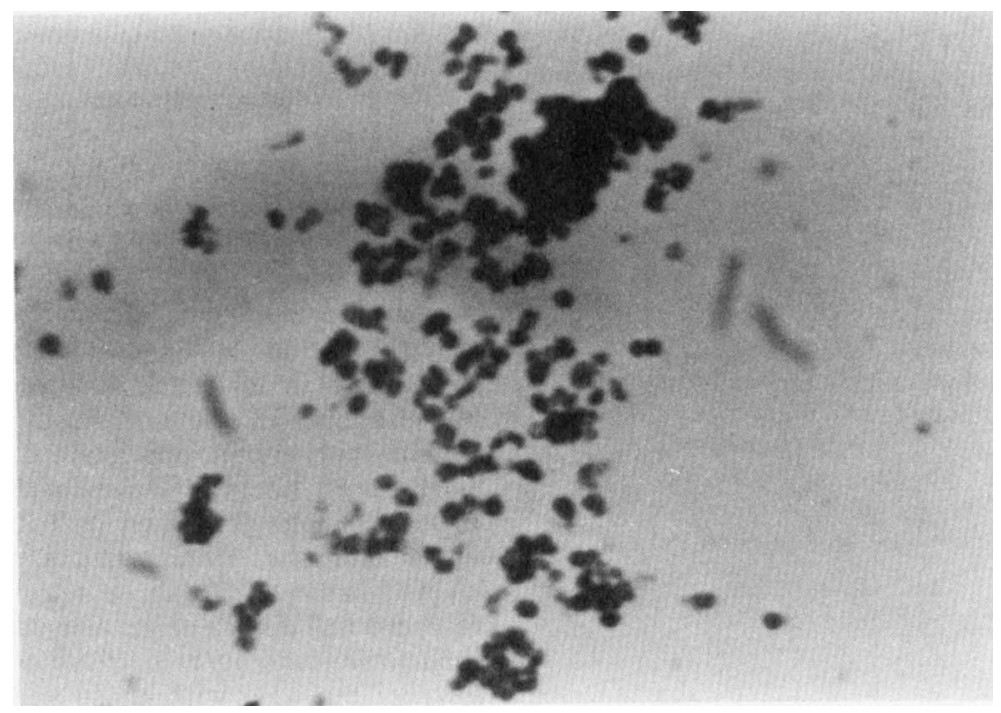

FIG. 1. Cellular morphology of Fusobacterium perfoetens PVA $B_{3} / 63$. Gram stain of 24-h-old Rosenow broth culture. Magnification, $\times 1,000$.

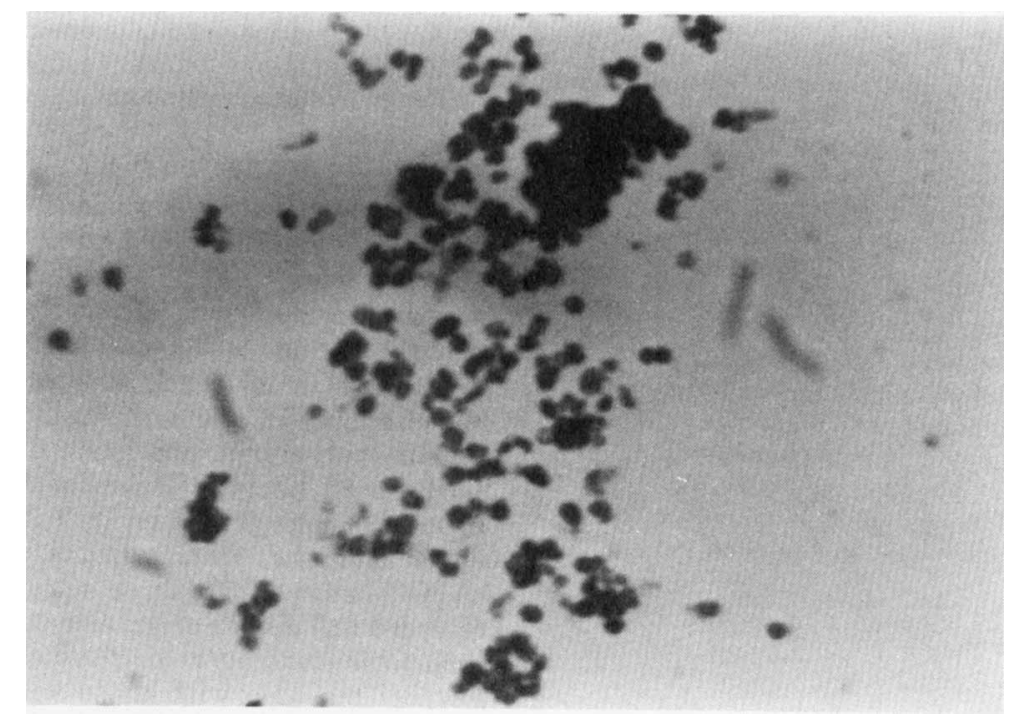

Fig. 2. Cellular morphology of Fusobacterium perfoetens PVA $B_{3} / 63$. Gram stain of 24-h-old PYG-broth culture. Magnification, $\times 1,000$.

tion, although cultures on surface-inoculated blood agar plates exposed to the air for $24 \mathrm{~h}$ and later incubated in an anaerobic GasPak jar grew very well.

The other biochemical characteristics of the six isolates are in good agreement with the characteristics cited in the aforementioned descriptions of this organism. Tissier stated that $B$. perfoetens fermented only glucose and su- crose. We obtained the same results, although weakly positive reactions were noted with fructose, galactose, trehalose, and mannose.

The $\mathrm{G}+\mathrm{C}$ content of the DNA of $S$. perfoetens described by Sebald (1962) (10) (chromatographic separation) was $30 \mathrm{~mol} \%$. Using a method based upon absorbancy ratios (2), we found a G+C content of $28.2 \mathrm{~mol} \%$ for strain PVA $_{3} / 63$. 
TABLE 1. Characteristics of Fusobacterium perfoetens

\begin{tabular}{|c|c|c|c|c|}
\hline Characteristic & $\begin{array}{l}\text { Isolate } \\
\text { PVA } \\
\mathrm{B}_{3} / 63^{a}\end{array}$ & $\begin{array}{l}\text { Five } \\
\text { other } \\
\text { iso- } \\
\text { lates }\end{array}$ & $\begin{array}{l}\text { Weinberg } \\
\text { et al. (12) }\end{array}$ & $\begin{array}{l}\text { Prévot } \\
\text { et al. } \\
\text { (9) }\end{array}$ \\
\hline Gas from glucose & + & + & + & + \\
\hline Hemolysis & - & - & $\cdot$ & $\cdot$ \\
\hline $\begin{array}{l}\text { Catalase produc- } \\
\text { tion }\end{array}$ & - & - & $\cdot$ & . \\
\hline $\begin{array}{l}\text { Motility } \\
\text { Production of: }\end{array}$ & - & - & - & - \\
\hline $\begin{array}{l}\text { Indole } \\
\mathrm{H}_{2} \mathrm{~S}, \mathrm{CO}_{2}, \mathrm{NH}_{3}\end{array}$ & $\begin{array}{l}- \\
+\end{array}$ & $\begin{array}{l}- \\
+\end{array}$ & $\overline{+}$ & $\overline{+}$ \\
\hline Growth in: & & & & \\
\hline $\begin{array}{l}20 \% \text { Bile } \\
\text { Brilliant green } \\
(0.001 \%)\end{array}$ & $\overline{+}$ & $\begin{array}{l}- \\
+\end{array}$ & • & $\cdot$ \\
\hline $\begin{array}{r}\text { Polymyxin } \\
(0.001 \%)\end{array}$ & - & - & $\cdot$ & · \\
\hline Nitrate reduction & - & - & . & • \\
\hline Esculin hydrolysis & - & - & $\cdot$ & . \\
\hline Milk clotting & - & - & - & - \\
\hline$\underset{\text { Propionate }}{\text { threonine }} \leftarrow$ & + & + & $\cdot$ & · \\
\hline $\begin{array}{l}\text { Threonin deami- } \\
\text { nation }\end{array}$ & + & + & $\cdot$ & · \\
\hline Gelatin & - & - & $\cdot$ & · \\
\hline $\begin{array}{l}\text { Acid from: } \\
\text { Amygdaline }\end{array}$ & - & - & . & . \\
\hline Arabinose & - & - & . & . \\
\hline Cellobiose & - & - & . & . \\
\hline Dextran & - & - & - & - \\
\hline Fructose & $\mathbf{w}$ & $\mathbf{w}$ & . & . \\
\hline Galactose & $\mathbf{w}$ & $\mathbf{w}$ & . & - \\
\hline Glucose & A & A & + & + \\
\hline Glycerol & - & . & . & . \\
\hline Lactose & - & - & - & - \\
\hline Maltose & - & - & . & - \\
\hline Mannitol & - & - & . & . \\
\hline Mannose & w & $\mathbf{w}$ & . & . \\
\hline Melibiose & - & - & - & - \\
\hline Raffinose & - & - & . & - \\
\hline Rhamnose & - & - & . & - \\
\hline Ribose & - & . & . & - \\
\hline Salicin & - & - & . & . \\
\hline Sorbitol & - & . & . & - \\
\hline Sucrose & A & $A(w)$ & + & + \\
\hline Trehalose & $\mathrm{w}$ & $\mathbf{w}$ & . & - \\
\hline Xylose & - & . & . & - \\
\hline
\end{tabular}

Acids from PY-

glucose broth cultures $(\mathrm{meq} / 100 \mathrm{ml})$

Acetic

\begin{tabular}{ccccc} 
Average & 0.3 & 0.4 & - & + \\
$\begin{array}{c}\text { Range } \\
\text { Butyric }\end{array}$ & $0.1-0.6$ & $0.1-0.9$ & & \\
$\quad$ Average & 1.4 & 1.5 & + & + \\
$\begin{array}{l}\text { Range } \\
\text { Lactic }\end{array}$ & $1.1-1.9$ & $1-2.5$ & & \\
$\quad \begin{array}{c}\text { Average } \\
\text { Range }\end{array}$ & 1.0 & 1.2 & + & + \\
Valeric & $0.8-1.3$ & $0.6-1.8$ & & \\
\hline
\end{tabular}

${ }^{a}$ Results from five replicate test sets. Symbols: + , positive reaction ( $100 \%$ of the strains or of the test sets positive); - , negative reaction; $\mathrm{A}, \mathrm{pH}$ below $5.7 ; \mathrm{w}, \mathrm{pH} 5.7$ to $6.0 ; \cdot$, not tested or reported.
TABLE 2. Susceptibility of Fusobacterium perfoetens strains to antibiotics

\begin{tabular}{lccc}
\hline & $\begin{array}{c}\text { Antibiotic } \\
\text { conc }(\mu \mathrm{g} / \\
\text { disk) }\end{array}$ & \multicolumn{2}{c}{$\begin{array}{c}\text { Zone diam (mm) of } \\
\text { inhibition of: }\end{array}$} \\
\cline { 3 - 4 } & & $\begin{array}{c}\text { PVA } \\
\text { B }_{3} / 63^{b}\end{array}$ & $\begin{array}{c}\text { Five other } \\
\text { isolates }\end{array}$ \\
\hline Aureomycin & 30 & 25 & $25-27$ \\
Ampicillin & 10 & 6 & 6 \\
Bacitracin & $10^{c}$ & 6 & $\cdot . d$ \\
Carbenicillin & 50 & 6 & 6 \\
Clindamycin & 2 & 30 & $29-34^{\circ}$ \\
Chloramphenicol & 30 & 24 & $23-28$ \\
Colistin & 10 & 17 & $16-18$ \\
Erythromycin & 15 & 6 & $\cdot$ \\
Kanamycin & 30 & 6 & $\cdot$ \\
Neomycin & 30 & 6 & $6-12$ \\
Oleandomycin & 15 & 6 & $\cdot$ \\
Penicillin & $10^{c}$ & 6 & $\cdot$ \\
Polymyxin & $300^{c}$ & 17 & $17-19$ \\
Rifampin & 30 & 17 & $18-22$ \\
Terramycin & 30 & 27 & $25-33$ \\
Tetracycline & 30 & 24 & $23-29$ \\
Vancomycin & 30 & 6 & 6 \\
\hline
\end{tabular}

${ }^{a}$ Filter paper disks $(6 \mathrm{~mm}$ in diameter; BBL susceptibility disks).

${ }^{b}$ Results are mean values of three replicates.

c Antibiotic concentration expressed in units.

"Not tested.

${ }^{e}$ Range of diameter of zone.

The susceptibilities of the six isolates to a number of antibiotics is given in Table 2 . All of the isolates had the same antibiotic susceptibility. They were resistant to penicillins, erythromycin, oleandomycin, bacitracin, vancomycin, kanamycin, and neomycin. They were highly susceptible to tetracyclines, chloramphenicol, and clindamycin and moderately susceptible to colistin, polymyxin, and rifampin.

Proposed neotype strain of $F$. perfoetens. From the data presented in Table 1, it is obvious that the characteristics of PVA $\mathrm{B}_{3} / 63$ (ATCC strain 29250) agree not only with those recorded in Tissier's original description of $\mathrm{Coc}$ cobacillus anaerobius perfoetens (syn.: F . perfoetens) but also with those subsequently described for this species by Weinberg et al. (12), Prévot (8), and Séblad (10). Therefore, we propose strain PVA $B_{3} / 63$ as the neotype strain of Fusobacterium perfoetens (Tissier) Moore and Holdeman.

\section{ACKNOWLEDGMENTS}

We are grateful to J. De Ley, Laboratory of Microbiology and Microbial Genetics, State University Gent, Belgium, for advice and assistance and for the determination of the DNA base compositions. We thank L. Servaes for technical assistance rendered during the course of this study. 
This investigation was supported by a grant of the I.W.O.N.L., Brussels, Belgium.

\section{REPRINT REQUESTS}

Address reprint requests to: $P$. Van Assche, University of Gent, Laboratory of Industrial Fermentations, Faculty of Agricultural Sciences, Coupure links 533, 9000 Gent, Belgium.

\section{LITERATURE CITED}

1. Buttiaux, R., H. Beerens, and A. Tacquet. 1969. Manual of bacteriological techniques, 3rd ed. Flammarion Medicales, Paris.

2. De Ley, J. 1967. The quick approximation of DNA base composition from absorbancy ratios. Antonie van Leeuwenhoek J. Microbiol. Serol. 33:203-208.

3. Hauduroy, P., G. Ehringer, A. Urbain, G. Guillot, and J. Magrou. 1937. Dictionnaire des bactéries pathogènes. Masson and Co., Paris.

4. Holdeman, L. V., and W. E. C. Moore. 1972. Anaerobe laboratory manula. Virginia Polytechnic Institute Anaerobe Laboratory, Blacksburg, Va.

5. Holdeman, L. V., and W. E. C. Moore. 1974. In R. E.
Buchanan and N. E. Gibbons (ed.), Bergey's manual of determinative bacteriology, 8th ed. The Williams and Wilkins Co., Baltimore.

6. Marmur, J. 1961. A procedure for the isolation of deoxy. ribonucleic acid from micro-organisms. J. Mol. Biol. 3:208-218.

7. Moore, W. E. C., and L. V. Holeman. 1973. New names and combinations in the genera Bacteriodes Castellani and Chalmers, Fusobacterium Knorr, Eubacterium Prévot, Propionibacterium Delwich, and Lactobacillus Orla-Jensen. Int. J. Syst. Bacteriol. 23:6974.

8. Prévot, A. 1957. Manuel de classification et de détermination des bactéries anaérobies. Masson and Co., Paris.

9. Prévot, A. R., A. Turpin, and P. Kaiser. 1967. Les bactéries anaérobies. Dunod, Paris.

10. Sébald, M. 1962. Etude sur les bactéries anaérobies. Gram-négative asporuleés. Imprimerie Branéoud S.A., Laval.

11. Tissier, H. 1900 . Recherches sur la flore intestinale des nourrissons. Thésis, University of Paris.

12. Weinberg, M., R. Nativelle, and A. R. Prévot. 1937. Les microbes anaérobes. Masson and Co., Paris. 